\title{
レスキューロボットとソフトマテリアル
}

\author{
松 野 文 俊*1. 桑 原 裕 之*2 ・伊 能 崇 雄*3 \\ 広 瀬 茂 男*4.津久井 慎 吾*5
}

\section{The Rescue Robot and the Soft Material}

Fumitoshi MATSUNO ${ }^{1}\left({ }^{1}\right.$ The University of Electro-Communications), Hiroyuki KUWAHARA ${ }^{2}$, Takao INOH ${ }^{2}$, ( ${ }^{2}$ NPO International Rescue System Institute), Shigeo HIROSE ${ }^{3}$, ( ${ }^{3}$ Tokyo Institute of Technology), Shingo TSUKUI , ( ${ }^{4}$ TOPY INDUSTRIES, LIMITED)

In this paper, we introduce the newest rescue robots which we have been developing and some applications of soft material for rescue robots.

Rescue robots are expected in the field of searching victims as the first application. The mobility on rubble is in one of the technology required in order to attain development. In order to make robots possible to run over rubbles, we adopted track crawlers using soft material as mobile mechanism for rescue robots. Using soft material is very effective to get traction on an edge of the stair to climb up the stairs. Improvement of the quality of the soft material will be expected from now on.

Key Words : Rescue robot, Deliverer search, Rubble, Rubber-Crawler, Stairs Climbing

1.は じめ に

1995年 1 月 17 日に発生した阪神淡路大震災は 6000 人以 上の尊い命を奪った。また，最近では新潟中越地震やスマ トラ沖地震の津波による災害も大きな犠牲を伴った。これ らの自然災害だけではなく，チェリノブイリ原発事故や $\mathrm{JCO}$ の事故, サリンなど化学物質によるテロ, ニューヨ 一ク世界貿易センタービルの旅客機を用いたテロなど人為 的災害も後を絶たない。被害の未然防止には限界があり， 発災直後のレスキューは，直接人命を左右し極めて重要で ある。

また，阪神淡路大震災でのデータでは瓦砂の中に埋もれ た要救助者を 72 時間以内に救出しないと, その生存確率 は $5 \%$ 以下になってしまうことが報告されており，迅速な 人命救助が望まれる。そこで，人が近づくには危険な場所 の情報収集や人命救助のためのレスキューロボット・シス テムの研究開発が注目を浴びている.

このような背景から, 文部科学省は 2002 年度より 5 年 間のプロジェクトとして大都市大震災軽減化特別プロジェ クト(大大特プロジェクト)を開始した。国際レスキューシ ステム研究機構は被災者救助等の災害対応戦略の最適化に おける「レスキューロボット等次世代防災基盤技術の開発」
プロジェクトを受託し，研究開発を推進している．国際レ スキューシステム研究機構 (IRS) は産官学民の英知を集結 して，大規模災害から人を救い出すレスキューシステムを 構築することを目的に 2002 年 4 月 18 日に設立された特定 非営利活動法人 $(\mathrm{NPO})$ である.

本稿では, IRSが開発しているレスキューロボットのう ちクローラ型のロボットを紹介し， ロボットの走破性を高 めるためのソフトマテリアルの活用事例について述べる.

\section{IRSにおける研究開発課題と想定シナリオ}

IRSは神戸市と川崎市にラボラトリーを設置し, 研究協 力者も合わせると 200 名以上の研究者が

1）情報収集ロボット：移動技術，情報マッピング

2）インテリジェントセンサーと携帯端末：情報収集技 術，分散統合センシング技術

3）ヒューマンインターフェイス：遠隔操作技術，情報 提示技術

4）総合システム の 4 つのテーマを中心に，レスキューロボット・情報シス テムの開発研究を行っている.

IRSが大大特プロジェクトで推進しているレスキューロ ボット・システム開発研究では，まず 2002 年からの 5 年 間で，人間が近寄れない災害現場等において情報を収集す 
るロボットを開発することを目的としている。2005年度 からは，実災害でのレスキューロボットシステム運用シナ リオを考え，以下の 4 つのミッションユニット (MU)のも と研究開発を進めている。

1 、上空移動体を用いた情報収集 $M U$ (上空 $M U)$

2．瓦礫上移動体を用いた情報収集 $M U$ (瓦礫上 MU)

3 . 瓦礫内移動体を用いた情報収集 $M U$ (瓦礫内 $M U)$

4. 広域災害情報収集のための社会インフラ MU（インフ ラ MU)

レスキューロボットシステム運用シナリオとして以下の ように考えている.

- 平時

平時にはインフラ MUの航空機，分散センサ，ネットワ ーク家電，PDAにより収集された情報とシミュレーショ ングループ(大大特プロジェクトの他のグループ)によって 開発されている包括的災害救助シミュレータによってGIS （地理情報システム：Geographic Information System）上 に防災マップが整備される。また，災害現場を模したテス トフィールドでロボット活用の現場訓練がなされる.また， 平時の 3 次元 GISデータを基にシミュレーションにより仮 想的な災害空間を構築し，仮想避難訓練や仮想空間におけ るレスキューロボットの遠隔操作訓練に活用する。

- 発災直後

発災直後には上空 MUのインテリジェントヘリが出動 し，カメラやレーザーレンジファインダーなどの搭載セン サを用いて，被災地の大域的な情報を収集する。これらの 情報を集約し; 被害の大域的な状況をGISを用いて提示し， 状況の正確な把握と，どの地域にどのMUを向かわせるか の対応戦略策定，意思決定の支援を行う。

·発災数時間後

上空MUの飛行船やバルーンは情報タグ, 携帯アンテナ, 赤外線カメラなどで被災者情報を収集するとともに，カメ ラやレーザレンジファインダなどを用いて詳細な環境マッ プを作成し，さらに救助隊・瓦礫上のレスキューロボット や瓦礫内のレスキューロボットの位置同定や通信中継など の行動支援を行う。瓦碟上MUでは救助隊により倒壊現場 に投入されたロボットが瓦磁の上の比較的局所的な範囲を 移動し，カメラなどで被災者情報を収集するとともに，構 造破壊の状況やガスや危険物の状況を調査する。瓦磁内 MUでは救助隊により倒壊現場に搬入されたロボットが瓦 礫の上や横の開口部から瓦礫内に投入され，遠隔操作によ り移動し，赤外線カメラ，温度センサーなどのセンサーを 用いて瓦礫内の被災者情報を収集する，インフラ MU ・上 空MUにより収集された情報はグローバルマップ上に，瓦 磁上MU・瓦碟内MUによって収集された情報はローカル マップ上 (グローバルマップ上では点となり，ローカルマ ップはその点にリンクされる)にマッピングされる。マッ
ピングされた情報に基づいて，救助隊がアドバンストッー ル(瓦礫内MUで開発)をもって救助を行う。また，マッピ ングされた情報のうち日常生活に必要なものをインフラ MUの情報インフラや上空 MUの気球を用いて住民に配信 する.

IRSではこのような想定シナリオを実現でき，想定外の 事態にもロバストに対応できるシステムを実現するために 研究開発を推進している。

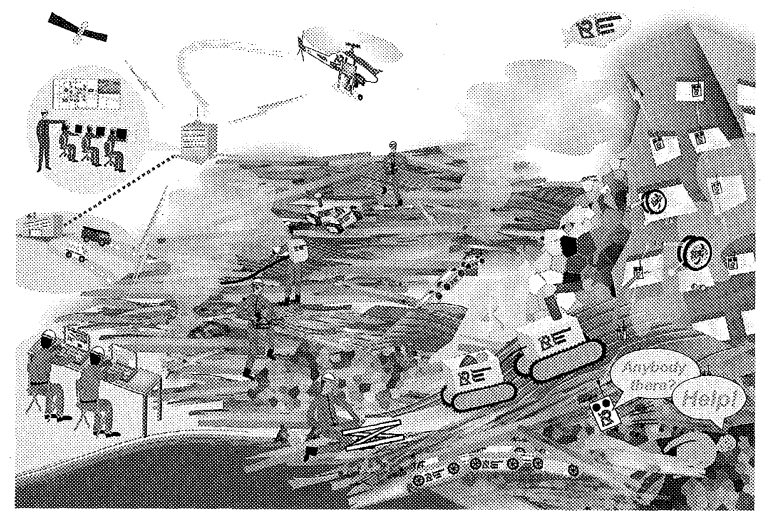

Figure 1 Employment of a rescue robot

\section{3. 最新レスキューロボットの紹介}

\section{1 探査用へビ型ロボット「IRS 蒼龍」}

「IRS 蒼龍」は東京工業大学広瀬茂男教授と IRS との共 同で開発されたレスキューロボットである，広瀬研ではこ れまでに非常に荒地走破能力の高い「蒼龍」1)，2）という ロボットを研究してきており，その 3 作目である蒼龍 3 号 機を元に実作業現場の環境に対応できるよう防水防塵構造 を取り入れ，各種センサの搭載などの改良を行ったものが IRS蒼龍である.

\section{1 .1 開発コンセプト}

大大特プロジェクトの研究開発の中で，倒壊した家屋や 倒壊の危険のある建物のなかに閉じ达められるなど救助を 求めている被災者を探し出すためのロボットとして IRS 蒼 龍は位置付けられている，蛇型であるIRS蒼龍はその細さ によって瓦礫の狭い隙間などから建物内部に侵入すること ができ，その長さによって倒れた机などの高い障害物を乗

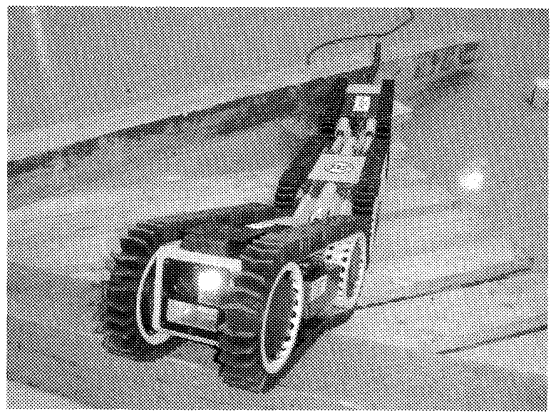

Figure 2 IRS Souryu

全長 $1200 \mathrm{~mm}$ ，全幅 $130 \mathrm{~mm}$ ，全高 $120 \mathrm{~mm}$ 


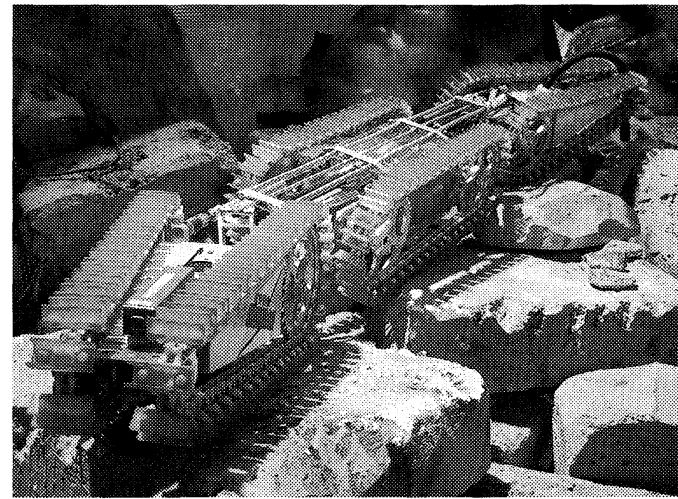

Figure 3 Souryu I 全長 $1200 \mathrm{~mm}$ ，全幅 $180 \mathrm{~mm}$ ，全高 $150 \mathrm{~mm}$

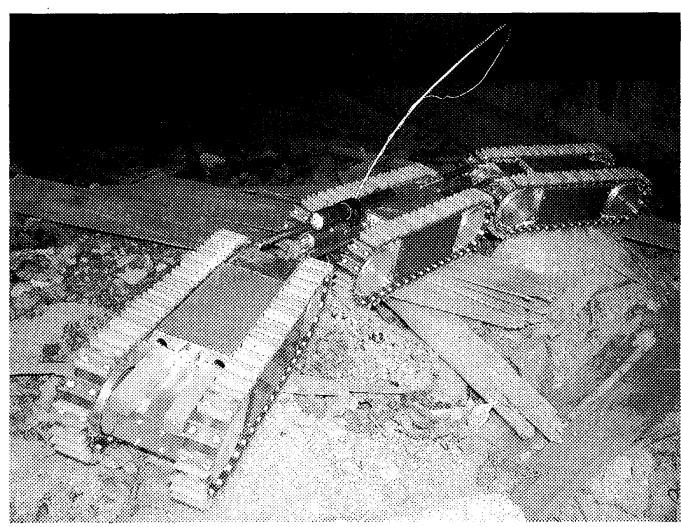

Figure 4 Souryu III 全長 $1200 \mathrm{~mm}$ ，全幅 $130 \mathrm{~mm}$ ，全高 $120 \mathrm{~mm}$

り越え，前進していくことができる，そして，これまでよ りも早く被災者を発見し，さらにこれまでは不可能だった 場所へ捜索の範囲を広げることで，より多くの生命を救う ことができると考えられる。

\section{1 .2 IRS 蒼龍による効果}

このIRS蒼龍は離れたところから有線でリモコン操縦を 行うようになっている。レスキュー隊が被災者探査ツール として使用することで，レスキュー隊員が自分自身の安全 を確保しつつ探索作業を行うことができ，さらにこれまで 危険なため探索活動ができなかったエリアへの探索範囲を 広げることができると考えられる.

また，探索活動のためにあらかじめ行うレスキュー隊員 の安全確保や障害物撤去作業などの付帯作業は, 探索の結 果被災者が見つからなかった場合には無䭾な作業となって しまう。しかしIRS荅龍を用いることでそれら付带作業な しに探索活動が行える可能性があり, 探索作業における作 業時間，労力ともに大幅な節約がみこめる．そのため，よ り広範囲の探索活動をより迅速に行うことができると考え られる。

\section{1 .3 IRS 蒼龍の構造}

IRS 蒼龍は構造や寸法などは蒼龍 3 号に準じており，全 長 $1200 \mathrm{~mm}$, 全幅 $130 \mathrm{~mm}$, 全高 $120 \mathrm{~mm}$, 重量約 $12 \mathrm{~kg}$, 最 大段差乗り越え $400 \mathrm{~mm}$ と, その高い走破性能を継承して
いる.

本体は前節，中節，後節の 3 節に分離した構造をとって おり，それぞれに 1 対の走行用クローラを装備している. また，それぞれの節と節の間は 3 本のリンクにより接合さ れており, そのうち 2 本のリンクの長さをそれぞれ変化さ せられるようになっている。これらを制御することで節間 の角度を操作できるようになっている。

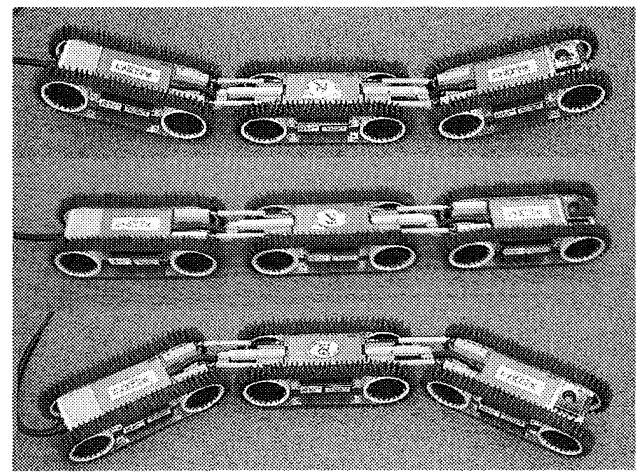

Figure 5 Body bending

\subsubsection{IRS 蒼龍の操作性}

IRS 蒼龍は走行のため，3つの節それぞれに 1 対のクロ ーラが搭載されているが，対となるクローラは機械的に接 続され同時に動くようになっている，さらに，それぞれの クローラを駆動する走行用モー夕には同じ速度指令值が与 えられるようになっている。 つまり，1つの指令值で 3 対 6 本のクローラが一度に回転する。

節間はリンクの長さを変更することでその角度を変化さ せるが，前節と中節，中節と後節にあるリンクは機械的に 接合されており, その長さも連動して変わるようになって いる．よって, 前節と中節の角度を変えると中節と後節の 角度も等しく変わることになる。 これらの機構によって, IRS 蒼龍は推進速度, 節間上下角, 節間左右角の 3 つの指 令值で動作するよう構成されており, 操縦者に直感的な操 縦ができるようになっている.

\section{1 .5 IRS 蒼龍の搭載センサー}

IRS蒼龍にはリモコン操縦で被災者の探索を行うために いくつかのセンサー類を搭載している，後節上部の超広角 カメラでは, 自分の姿勢も含めた周囲の状況を把握するこ とができるようになっており, 操縦者はこの映像をモニ夕 一で見ながら IRS荅龍を瓦礫内に進めていく．また，前節 先端には対象物観察用カラーCCD メラとサーモビジョ ンが取り付けられている。 サーモビジョンは対象物の温度 が高いものほど白く写る長波長赤外線カメラで, 暗闇や表 面が粉塵で覆われ目視でも被災者が判別できないようなと きでも被災者と認識することができるカメラである.また， 前節先端部にはステレオマイクとスピーカーが搭載されて いる.このスピーカーによって, 倒壞家屋へ進入しながら "誰かいませんか"というように被災者への呼びかけをおこ 


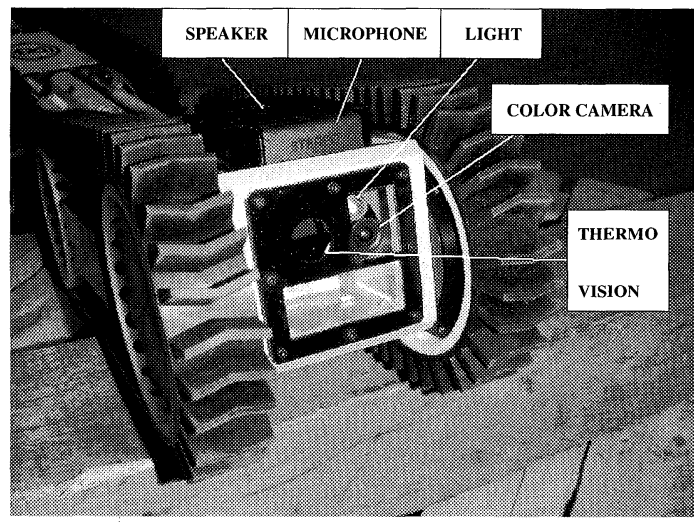

Figure 6 Sensors

ない，マイクによってその返答を聞き取ったり，合図の音 を拾ったりすることで捜索を行う。さらに，被災者を発見 した場合には周囲の状況や他の被災者について聞きだした り，救助までのあいだ励ましたりすることに使用できる. 他にも, 対象までの距離を測るレーザー測距計や本体の姿 勢を計る重力センサー, 温度センサーなどを搭載する。必 要に応じて, 酸素濃度計や有毒ガスセンサーの搭載も考え られる。

\section{1 .6 IRS 蒼龍の今後}

現状でIRS蒼龍は実用化に極めて近いロボットである。 このIRS蒼龍を用いた震災現場での動作試験を行い，また レスキュー隊員との意見交換を行うなどして開発を進めて いる. 現在は実験等で判明した問題点をもとに改良型の蒼 龍を製作中である。製造コストや運用方法などまだまだ問 題は多いが，現実にIRS蒼龍が被災者探索を行うのもそれ ほど遠い未来ではないと考えている.

\section{2 作業型不整地走行クローラ車両「HELIOS VII}

HELIOS VII も, 東京工業大学広瀬茂男教授と IRS との共 同で開発されたレスキューロボットで，レスキュー活動に おける偵察や要救助者の探査及び作業補助を目的として開 発されたクローラ車両である，HELIOS VII の特徴は，不整 地走破に作業アームを使用するというコンセプトを設計に 取り入れることによって，多様な運用が可能であるという 点にある。

\section{2 .1 開発コンセプト}

都市部での震災など広域災害における救助作業の機械 化、効率化は極めて重要な課題であり，近年ではロボット 技術の応用も検討されている. 救助作業の現場は瓦磁など により通常の走行手段では移動困難であるため, 救助活動 を行う機械は作業能力だけでなく高い対地適応性能が求め られている. HELIOS VIIは，これまで行われた数多くのス タイルのクローラ車両の研究，開発から得られた知見に, 作業アームを不整地走破に使用するというコンセプトを付 加することで，これまでの開発実績に基づく高い実用性に 加え作業能力と更に高い対地適応性を得ることを狙ったも

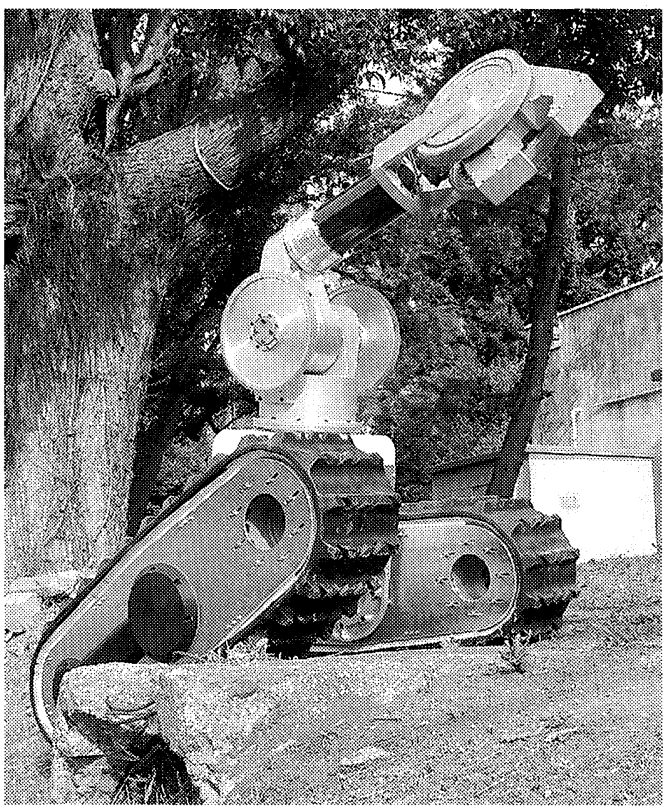

Figure 7 HELIOS VII

全長 $700 \mathrm{~mm}$ ，全幅 $600 \mathrm{~mm}$ ，全高 $250 \mathrm{~mm}$

のである。

\subsubsection{HELIOS VIIの構造}

HELIOS VII 以前でも走破性向上のために走行用アームを 設けるスタイルは存在したが, HELIOS VIIでは作業用のア 一ムの时や手先に受動車輪を設け，走行用アームと同様の 機能を持たせることで, 走破性向上のための付加装備なし で同様の効果を得るだけでなく，作業用アームの高い自由 度を生かして様々な局面における高い対地適応性と運用の 自由度を得ることに成功した。さらに，アームを連結器と して使用することにより複数台で連結して走破性を向上さ せるこれまでにない運用方法も視野に入れている。

\section{2 .3 HELIOSVIIの今後}

現在, 偵察や要救助者の探査用として数々のロボットが 試作されておりそれらのサイズと比較すると HELIOS VII の $700 \mathrm{~mm} \times 600 \mathrm{~mm} \times 250 \mathrm{~mm}$ (最小)というサイズは大型 の部類に入る (例えば，探査ロボット「蒼龍 I」であれば $1200 \mathrm{~mm} \times 180 \mathrm{~mm} \times 150 \mathrm{~mm})$ ）しかしながら，人が侵入 できない隙間を移動して探査を行う「蒼龍」とは異なり， 人が侵入できるサイズの空間を人の代わりに移動し探査を 行う, あるいは後続の救助隊の安全を確認, 確保するとい う目的を考えればこの大きさはむしろ手ごろであると言え る.

一方, HELIOS VII は重量が $80 \mathrm{~kg}$ 強と重く，運搬車から の積み下ろしなど人手で運搬されることを考慮すると運用 面で問題があると考えられる。そのため，全体のサイズを $3 / 4$ とした軽量化モデルであるHELIOS VIII 開発が HELIOS VIIの試験と平行して行われている. 

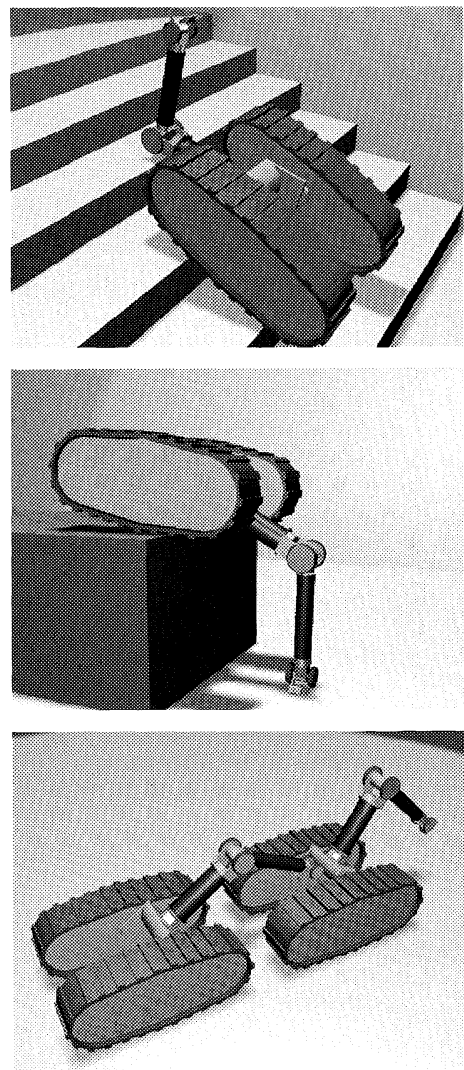

Figure 8 HELIOS VII Stairs Climbing, High Step climbing and Connection mode

\section{4. ソフトマテリアルの活用}

レスキューロボット実用化のための開発課題の 1 つとし て，ロボットが瓦礫フィールドを安定的に走破するための 移動体の不整地走破性, 障害物の乗り越え能力を向上させ る課題がある。これを実現するため現在移動体の足回りと してクローラを採用している。このクローラの部分でソフ トマテリアルが重要な役割を果たしている。以下に HELIOS シリーズの開発を通して対地適応を目的とした新 機軸の紹介を行い，最新レスキューロボットに採用したク ローラユニットを紹介する。

\section{1 対地適応を目的とした新機軸の紹介}

HELIOS は東京工業大学の梅谷・広瀬研究室において, 人の生活環境をはじめとする「人が活動する環境」に適応 した移動機構を，在来型の車輪やクローラを改良するとい うアプローチで実現することを目標に製作された一連のロ ボット群である，そこには，重心移動やクローラの摇動な どの新機構から車輪やクローラなどの接地点における工夫 など様々なアイデアが盛り込まれている.

初代モデル HELIOS I は, 在来のクローラ車両に重心 移動機構とクローラ表面に階段昇降用の伸縮スパイクを設 けたのが特徵である。一般に車両の重心位置はその高さに 応じて登坂や階段昇降時に谷側に移動するため, 車両が転 倒する危険性が増大する，人の生活環境においては階段の ような自然の地形では稀な急勾配がごく普通に存在する.
したがって,転倒防止のため重心の移動機構が必須である。 また，用途によっては荷室を水平に保ちたい場合もあるこ とを考えると重心の移動と荷室の水平を保つ 2 自由度が必 要になるがHELIOSでは，車両中央下部を回転中心とす るアームで荷室を支える構造を採用することにより 1 自由 度で重心移動と荷室の水平を実現している．また，クロー ラ表面の伸縮スパイクは, 段差や階段におけるエッジに引 っ掛けてトラクションを得るためのもので，伸縮方向には 柔らかく, 横方向 (車両の進行方向)には剛くという性質が 要求される。そのため板ばねを使用した機構を用いたのが 特徴である。

HELIOS II は摇動するクローラユニットを 4 つ装備した のが特徴で, これにより段差乗越え能力の向上, 車高調整, 信地旋回と超信地旋回におけるスリップロスの低減，傾斜 地横断を実現した。また，クローラ表面の伸縮スパイクも コイルスプリングを使用したタイプに変更している.

HELIOS III は, 段差や階段のエッジでトラクションを得 る方法として，伸縮スパイクではなくスプリング車輪を採 用したのが大きな特徴である，スプリング車輪とは，ゴム タイヤの代わりにコイルスプリングに摩擦係数向上とスプ リングの動きをある程度拘束するためのウレタンブロック を組み合わせたもので, 機構の単純化と部品点数の低減化 を狙ったものである。 また，重心移動機構も，車両中央下 部に回転中心を持つというこれまでのコンセプトを踏襲し つつ，低トルクで駆動できるように改良した RC (Remote Center) 機構を採用した.
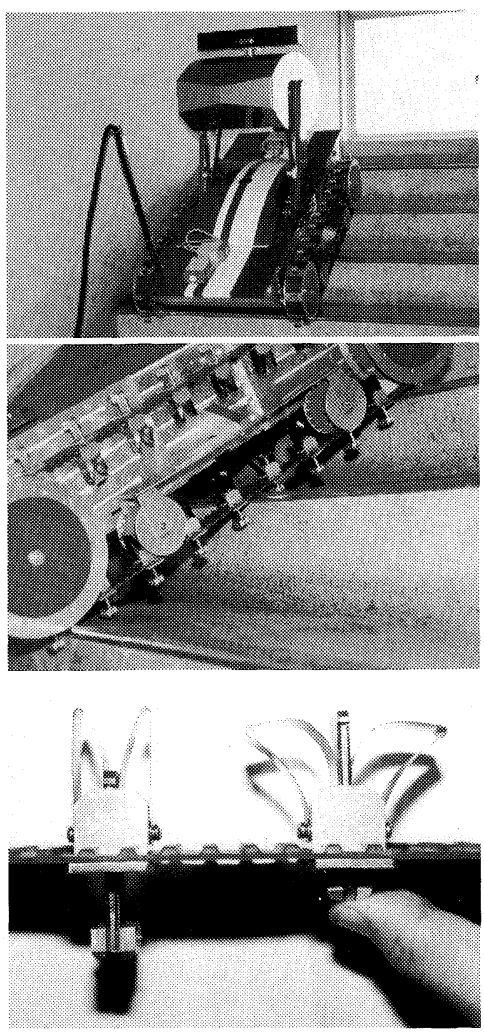

Figure 9 HELIOS I 
HELIOS IVでは，IIIのプリング車輪をさらに簡略化し， 低圧ゴムタイヤでエッジにおけるトラクションを得ること を狙った(Fig.12)，続く HELIOS Vでは，低圧夕イヤに輪 切り状に切れ込みを入れることによって，伸縮スパイクと 同様の効果を得ることを実現した (イカリングタイヤ) (Fig.13).

HELIOS VI，VIIでは，これまでのようにクローラやタイ ヤに複雑なギミックを持たせることをやめ，通常のゴムク ローラのラグパターンのみを工夫したものを採用した。伸 縮スパイクやスプリング車輪は段差乗越えや階段昇降にお いて効果があることは実験によって確認されているが，複 雑で部品点数が多く常時メンテナンスが欠かせないという マイナス面があったためである，そのかわりに，段差や階 段昇降の際に胴体を持ち上げるためのアームを装備するこ とで階段昇降などを実現した。

このように，HELIOSシリーズにおける対地適応の工夫 は大きく分けると重心移動機構と段差エッジにおけるトラ クションを得る方法の 2 つであり, 前者に関しては, 荷台 などの車体重量部を，車体中央下部を回転中心とするリン ク機構，あるいは RC 機構によって制御する機構設計が可

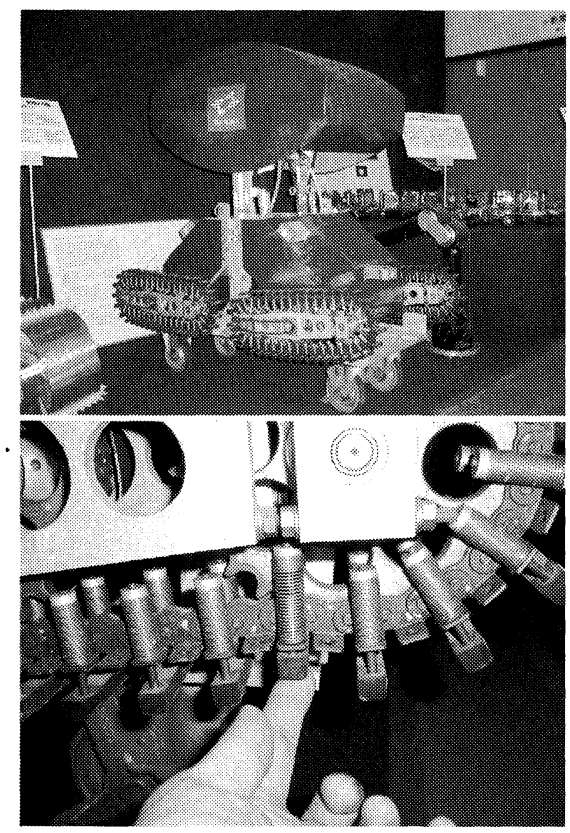

Figure 10 HELIOS II

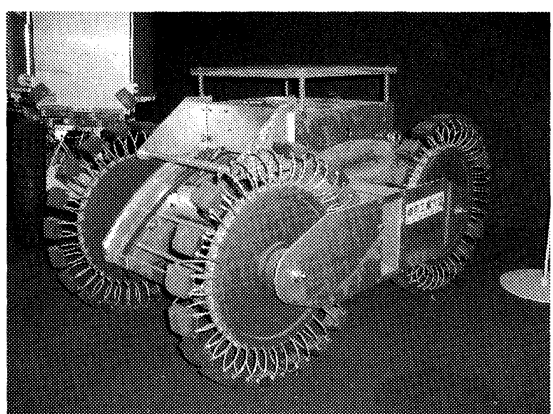

Figure 11 HELIOS III
能となった.

一方，後者に関しては，初期における機械的な仕組みを 使ったものから，コイルスプリング，切れ込みを持った夕 イヤ(イカリングタイヤ)とメンテナンス上の課題からソフ トマテリアルを活用し構造的にシンプルになるよう改良を 続け成果を挙げてきた. このことは, 段差エッジでも安定 したトラクションを得ることと，運用面において手間がか

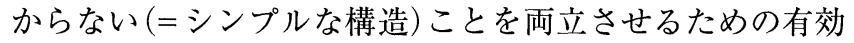
な手段において，ソフトマテリアルが重要な役割を果たし

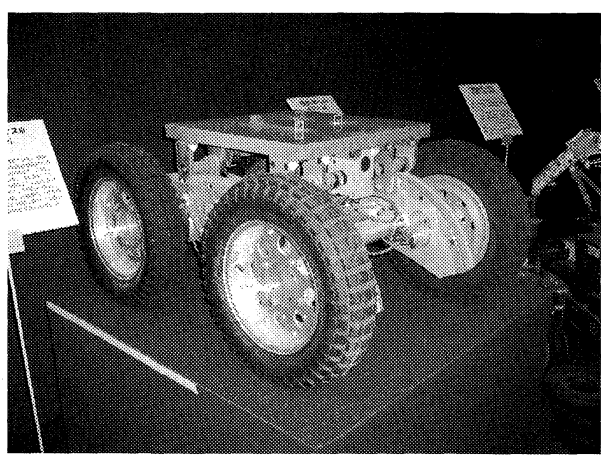

Figure 12 HELIOS IV
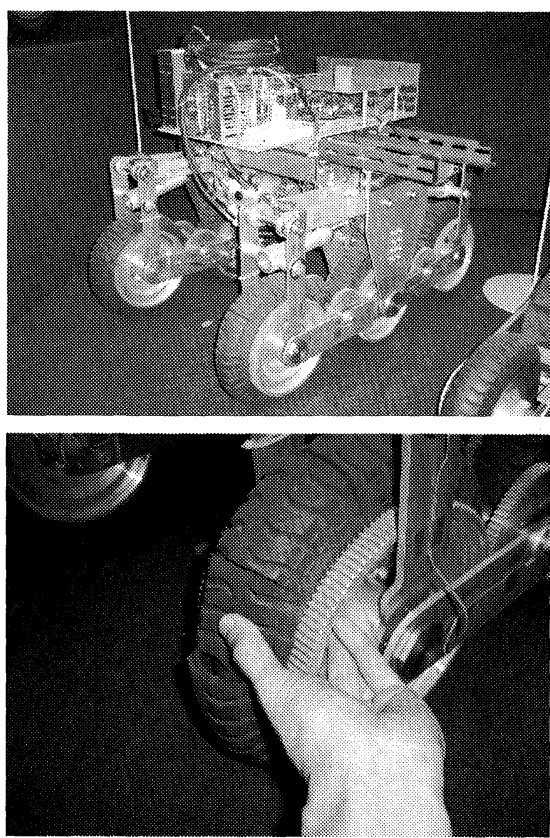

Figure 13 HELIOS V

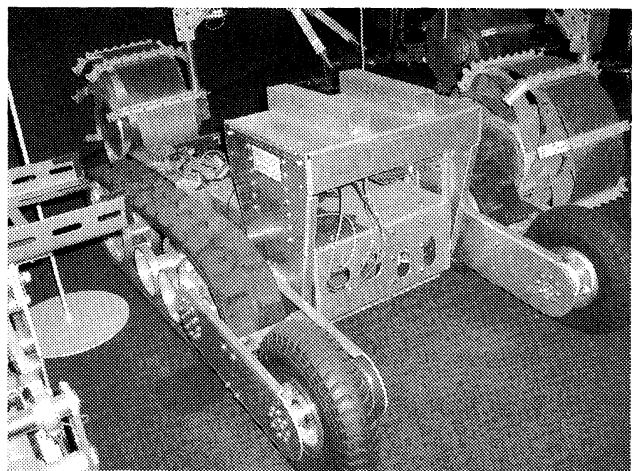

Figure 14 HELIOS VI 


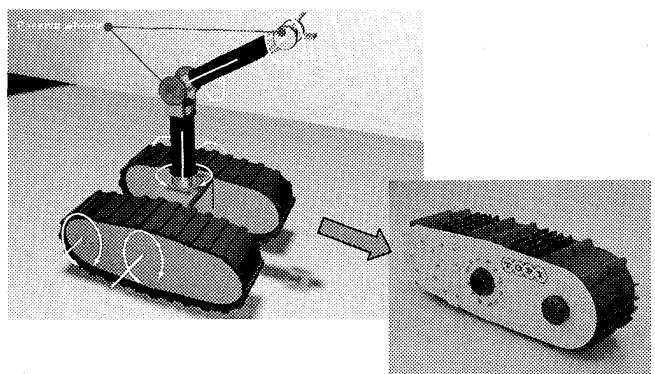

Figure 15 HELIOS VIII Crawler Unit

ていることを意味しており，今後さらにソフトマテリアル に注目していきたいと考えている。

\section{2 最新クローラユニットの紹介}

不整地走破性向上やロボット稼動時間の延長等，レスキ ユーロボットを実用化する上では，ロボット全体の軽量化 やエネルギー損失低減も重要である，クローラユニットに おいても，ユニット全体の軽量化やゴムクローラベルトの プリロードによる走行抵抗低減によるエネルギー損失低減 が必要であるが，クローラのサイズ的には農業機械用以下 のものとなり，このニーズを満たす既存製品は存在してい なかったが，東京工業大学の広瀬・米田研究室とトピー工 業(株が共同でロボット用の新機軸ゴムクローラを開発し た。開発品は超軽量，低走行抵抗，高不整地走破性を兼ね 備えることを開発コンセプトとしている。 さらにゴムクロ ーラベルトの伸びが少ないことにより，テンショナのスト ローク長が短縮でき，テンショナ構造を簡略化することで ユニット全体の軽量化も実現し, 防塵防水構造も取り入れ られ, 実作業現場の環境に対応できるモデルになっている. また開発品は，HELIOS シリーズの開発における対地適応 の知見より，段差エッジでトラクションを得る基本的な考 え方は初期の伸縮スパイクから変わってはいないが，それ を実現する方法として，機械的なカラクリを使用せずソフ トマテリアルの弾性変形を積極的に活用することで，非常 にシンプルな構造で瓦礫フィールドでの高不整地走破性を 実現していることから，「IRS蒼龍」と「HELIOS VIII」 （Fig.15）にロボット用の新機軸ゴムクローラを採用してい る.

\section{5.お わりに}

以上述べてきたように，不整地走破性，障害物の乗り越 え能力を開発課題の 1 つとしているレスキューロボットの クローラ足回りには，現在のところソフトマテリアルを活 用することが最も有効であると考えられている，今後レス キューロボットのクローラ足回りへの適用としてソフトマ テリアルに期待していきたいことは，寿命や耐熱性等実用 上の性能向上と瓦碟フィールドにおけるトラクション向上
である．後者においてはタイヤやクローラの形状だけでな くソフトマテリアルの材質的な工夫，例えば粗密や組成の 分布を制御した成型等によって新たな展開を見せることに なると考えている.

\section{参 考 文 献}

1) Takayama, T., Hirose, S.: Journal of Robotics and Mechatronics., 15, 61 (2003)

2 ) Takayama, T., Hirose, S.: Proceedings of 2004 IEEE/RSJ International Conference onIntelligent Robots and Systems September 28 - October 2, 2004, Sendai, Japan, 52 (2004)

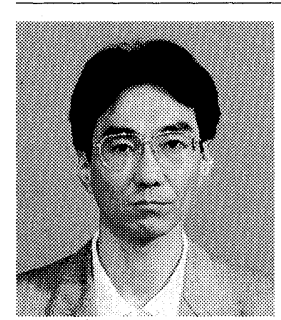

*1電気通信大学知能機械工学科 $(\overline{\mathrm{T}} 182-8585$ 東京都調布市調布ヶ 丘 1-5-1) 教授，工博. 昭和 61 年 (1986 年) 大阪大学大学院基礎工 学研究科博士後期課程修了. 専門分野は, ロボティクス, 制御工学, レスキュー工学.

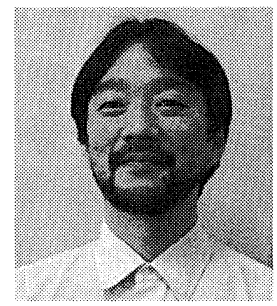

*2NPO 国際レスキューシステム研究機構 ( 210-0855 川崎市川崎区南渡田町 1-2(NKK 旧体育館))研究員. 平成 8 年, 東京工業大 学理工学研究科修士課程終了. 専門分野は, ロボティクス。

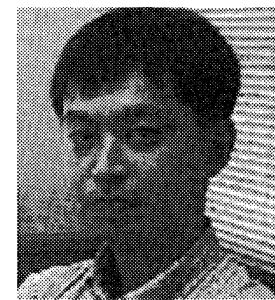

*3NPO 国際レスキューシステム研究機構 ( 210-0855 川崎市川崎区南渡田町 1-2(NKK 旧体育館) ) 研究員. 平成 6 年 東京工業大 学理工学研究科修士課程終了. 平成 6 年 (株)小松製作所入社. 研究本部中央研究所に て勤務の後，平成 14 年に退社. 同年, NPO 国際レスキューシステム研究機構の常勤研 究員として現在に至る。専門分野は, ロボ ティクス。

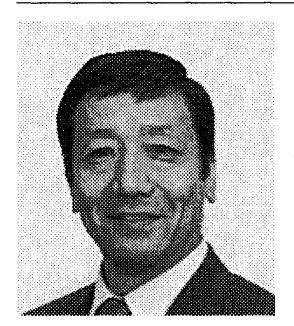

*4東京工業大学大学院械機械宇宙システム専 攻 ( T 152-8552 東京都目黒区大岡山 2-121) 教授, 工博. 昭和 51 年, 東京工業大学博 士課程制御工学専攻修了。専門分野は，口 ボットの創造設計, 災害救助ロボット，人 道的地雷除去ロボット他.

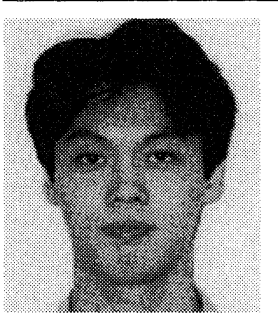

*5下ピー工業侏技術統括部技術研究所 ( 8510 豊橋市明海町 1 番地). 平成 5 年, 神 奈川工科大学工学部機械システム工学科卒 業. 同年，トピー工業秼入社，現在に至る. 専門分野は，機械システム。 